\title{
Perceived Service Quality, Trust, Customer Satisfaction and Customer Loyalty in the Banking Sector of Bukavu (East of DR Congo)
}

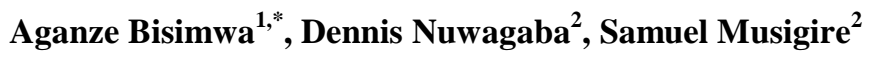 \\ ${ }^{1}$ Department of Financial Management, Université Evangélique en Afrique, Bukavu, DR Congo \\ ${ }^{2}$ Department of Marketing, Makerere University Business School, Kampala, Uganda \\ *Corresponding author: jacaganze@uea.ac.cd
}

Received June 28, 2019; Revised August 04, 2019; Accepted August 16, 2019

\begin{abstract}
This research studies customer loyalty in the banking sector in a very unstable region of East Democratic Republic of Congo by underlining the mediating role of customer satisfaction. It examines the relationship between perceived service quality, trust, customer satisfaction and customer loyalty in the banking sector of Bukavu by adopting quantitative cross-sectional research design and using self-administered questionnaires. Convenience sampling helps in collecting data from a sample of 225 respondents. Correlation and hierarchical regression help to test the research hypotheses. Customers perceive a relatively high quality of services they enjoy, their level of trust is relatively high and they are slightly satisfied. Consequently, they are moderately loyal to their respective banks. There are positive and significant relationships between the different couples of variables studied. There is $49.1 \%$ of variance explained in customer loyalty. Customer satisfaction positively and fully mediates perceived service quality and customer loyalty relationship and partially mediates trust and customer loyalty. Regular talks between banks and their customers should be privileged; customer satisfaction and loyalty should regularly be assessed and ethical values integrated.
\end{abstract}

Keywords: perceived service quality, trust, customer satisfaction, customer loyalty, Bukavu

Cite This Article: Aganze Bisimwa, Dennis Nuwagaba, and Samuel Musigire, "Perceived Service Quality, Trust, Customer Satisfaction and Customer Loyalty in the Banking Sector of Bukavu (East of DR Congo)." Journal of Business and Management Sciences, vol. 7, no. 3 (2019): 100-111. doi: 10.12691/jbms-7-3-1.

\section{Introduction}

In competing markets, loyalty has received particular attention from both scholars and practitioners in the banking industry [1]. References [2,3] and [4] argue that retaining existing customers is less onerous than attracting new ones. Customer loyalty is defined as the desire of clients to remain faithful to an organization [5] and continuing patronage over time [1]. Business sustainability for organizations can be achieved if their customers are loyal to them [6]. Thus, it is imperative that commercial banks create and maintain a loyal customer base $[7,8]$.

Prior literature [6], [8], [9] mentions the importance of perceived service quality in developing bank customer loyalty. According to [10] and [11], service quality is comprehended by customers as a difference between their expectations and their perceptions of the service delivered. For [12] and [13], excellence in service quality leads to satisfaction which helps in retaining customers for banks.

For customers to continue patronizing service providers, they must trust them and the services they offer (loans, deposits, withdrawals, etc.). In the banking context trust involves customer having confidence in the quality and reliability of the services offered [14]. Reference [15] argues that mutual trust between a bank and its customers reduces customer's perception of risk. Numerous studies $[8,16,17,18]$ evoke trust as a customer loyalty booster. Reference [8] argues that loyalty occurs where customers truly trust the bank.

As customers perceive high quality of services they enjoy and trust the organization and its services, they tend to be satisfied. Satisfaction is referred to by [16] as an instance where services and goods provided by particular organizations either meet or exceed customer needs and expectations. Scholars [13,16,19] advocate the role of satisfaction in improving bank customer loyalty. Reference [16] argues that a satisfied customer is likely to remain with the bank and to recommend it to others.

Democratic Republic of the Congo (DRC) is essentially characterized by a traditional banking sector oriented towards commercial banking and with a fierce competition [20]. Reference [21] reported that $29 \%$ of customers in DRC switch their banks because of poor service quality, $22 \%$ due to unfavorable interest rates and fees, $15 \%$ turnaround time taken to respond to requests and inquiries, $11 \%$ due to proximity of branches (long distances between bank branches and many of their customers, yet there are 
few ATM outlets), $2 \%$ change because of innovative products and services of the competing banks. Furthermore, the unstable banking system and the winding-up of some financial institutions led to the loss of trust among bank customers [22].

Although there are many studies on bank loyalty in Africa [8], little attention has been given to the context of DRC. This study fills this gap by focusing on the city of Bukavu. The banking sector of Bukavu presents some peculiar characteristics which include fierce competition from bank, nonbank and microfinance institutions, and bureaucracy in opening accounts and processing loan applications. Besides that, bank liquidity challenges have led customers to lose their trust in the banking system. On the other hand, some bank services are inconsistent with customers' needs leading to customer dissatisfaction [23]. Hence, this study intends to examine if there is any relationships between perceived service quality, trust and customer loyalty in the banking sector of Bukavu paying attention to the mediating role of customer satisfaction.

The remainder of this research paper is structured as follows. In the second section the study is positioned within the existing literature on the study variables. The third section presents the methodology adopted. Section 4 and 5 summarizes and discusses the empirical results respectively. In section 6 , conclusions and implications of the study are drawn and possible suggestions for further research are provided.

\section{Literature Review}

\subsection{Customer Loyalty (CL)}

Over the past decades, the concept of customer loyalty has been the subject of many researches in business industries [11]. Different scholars have underlined the role of customer loyalty in reducing marketing costs $[2,3,24]$. Others insist on the profit making aspect of customer retention [24]. Loyalty has been defined by [25] and [26] as the behavior of repeatedly patronizing the service provider and recommending the service provider to other customers. According to [4,17,27], it is referred to as a consumer's commitment to repurchase a preferred product and service consistently in the future.

The service marketing literature has experienced several contributions made for measuring the service loyalty [28]. It can be conceptualized either in terms of behavior or attitude [4,11,16,17,18,27,29,30]. As an attitude, it refers to a feeling that creates an attachment to the product or the service [4]. It encompasses the intention to re-patronize the service provider, the willingness to recommend the company to others, demonstration of commitment to the company and resistance to switch to competitors [4,16,27]. Reference [19] posits that attitudinal loyalty includes cognitive, affective and conative loyalty.

Loyalty behavior reflects customer attitude in terms of actions [4]. It refers to the repurchase of services in terms of frequency and proportion, and recommendations of the company to others through positive words of mouth $[4,27,31]$.

\subsection{Service Quality (PSQ)}

The importance of quality in service provision makes it imperative to focus on it in any study on services [24]. Service marketing literature identifies several ways of defining service quality. According to [32], service quality is the ability of a company to meet or exceed customer expectations. He evoked two components of quality relevant to service-providing organizations: technical quality also known as service outcome and functional quality or delivery process [16]. In the view of [10], it is the difference between customer expectations and their perceptions of the service delivered. Reference [33] considered it as the extent to which a service meets or exceeds customer needs and expectations.

Service quality is viewed as a multidimensional concept in the literature $[10,16,32,34,35,36,37,38]$ but there is no common agreement regarding its dimensions.

The [39]'s SERVQUAL model has been considered as the major instrument in the literature to measure quality [40]. The SERVQUAL instrument suggests that service quality can be measured by identifying the different gaps between customers' expectation and perceptions of the service performance. It uses the following five dimensions: tangibles, reliability, assurance, responsiveness, and empathy.

Although SERVQUAL has been supported and widely used to measure service quality in different service industries [13,41,42]; it is not without criticism: its validity, lack of specificity for some services, focus on only product/service and ignoring other Ps of the marketing mix [43]. To address these criticisms, other instruments have been developed. SERVPERF modified by [44] from the SERVQUAL used the performance only approach to measure perceived service quality and reported higher validity. Reference [43] also developed the Banking Service Quality (BSQ) instrument based on six dimensions: effectiveness and assurance, access, price, tangibles, service portfolio, and reliability.

\subsection{Trust}

The literature treating about trust in service industries is abundant. Trust has been examined from different perspectives, and its multiple definitions are provided. According to [45], trust exists when there is mutual reliability and integrity between partners. Reference [46] also defined trust as perceived credibility and benevolence of a service provider. Reference [47] conceptualized trust as the confidence that partners act in the interest of each other. For [48], it is a belief that each party will meet the wants and needs of the other. In banking, trust reflects the bank trustworthiness, honesty, integrity and reliability in delivering services to its customers [16]. These definitions highlight the importance of confidence and reliability in the conception of trust $[14,45]$. According to $[27,29]$, confidence is important as it serves in establishing true and collaborative relationships. References [10,24,49] underline the importance of trust in the service industries due to risk and uncertainty. References [50] and [24] argue that trust reduces perceived risk.

The following three dimensions of trust are widely accepted and used in research [51]: perceived credibility 
[46], benevolence [16,46,52,53] and integrity [16,53]. Integrity refers to the service provider's honesty, ethical actions and promise keeping [16,54]. Benevolence is defined as the service provider's caring and motivation to act in the customer's interest [54,55,56]. Perceived credibility refers to the belief that the service provider has the required skills and expertise to perform the service (competence or ability), the expectancy that the service provider's word or written statement can be relied on $[46,54,55]$.

\subsection{Customer Satisfaction}

Reference [57] mentioned the importance of customer satisfaction in developing and maintaining lasting relationships with customers. Reference [19] added that customer satisfaction plays an important role in long-term relationship with customer in the banking sector.

The interchangeable use of Customer satisfaction and service quality seems to have increased confusion in the marketing literature [58]. Reference [59] shared the opinion that favorable service quality perceptions lead to improved satisfaction. According to [60], service quality comes before and leads to overall customer satisfaction.

For [37] and [61], satisfaction results from customer perception and impression of the service performance and expectations. Reference [42] views it as the future intentions of customers towards the service provider. In [48]'s terms, customer satisfaction is an indication of how pleased is a customer with a product or a service. Satisfaction is also defined as an end-state that is derived from a previous purchasing experience, emerging as a cognitive reward or an emotional response to an experience [62].

In the marketing literature, satisfaction is often apprehended into two different approaches: either as specific transaction based satisfaction or as cumulative satisfaction $[17,63,64]$. Reference [65] and [58] argue that, in a context of bank loyalty study, satisfaction cannot be based on a single experience with the organization nor lead customers to switch their organization. Therefore, this study adopts the cumulative satisfaction approach [17].

According to [60], the lack of consensus in defining satisfaction creates obstacles in identifying its antecedents and consequences and renders arbitrary the development of satisfaction instrument measurements. This creates confusion in the operationalization of customer satisfaction [64]. Some researchers view customer satisfaction as a uni-dimensional concept [9]; others consider it through multiple dimensions consisting of service product, human element, non-human element, tangibles and social responsibility [64]. In line with [9], this study legitimizes the uni-dimensional approach of customer satisfaction and captures it using the items adapted from [41].

\subsection{Perceived Service Quality and Customer Loyalty}

The direct relationship between perceived service quality and customer loyalty is well documented. Considerable studies in the banking industry supported a positive relationship [1,4,8,11,13,16,19,38,66,67,68,69]. In Africa, [8]'s empirical review on the determinants of customer loyalty in the Sub-Saharan African banking industry reported a positive correlation between service quality and customer loyalty. Consistent with the aforementioned findings, this study hypothesizes that there is a positive relationship between perceived service quality and customer loyalty.

\subsection{Trust and Customer Loyalty}

Although customer satisfaction is a major driver of customer loyalty; let alone it is a necessary but not sufficient condition [70]. It is likely that, in the instances where there is lack of trust, satisfied customers may switch to competitors. Strong customer trust towards the service provider builds confidence that influences customer loyalty [18].

Prior studies [27,30,71,72] note the positive relationship between trust and customer loyalty in the service industry. Reference [56] contends that trust influences the customers' decision to leave or not an organization. Reference [71] studied the effect of customer trust on customer loyalty and customer retention under the moderating role of cause related marketing in cellular service operators in Pakistan and found that customers became loyal as their amount of trust increases. Likewise, [29]'s literature study on customer trust-customer loyalty relationship legitimized the positive influence of customer trust on customer loyalty. In the banking industry, the role of trust in developing customer loyalty is also supported $[16,17,18,24]$. Reference [17]'s study on Islamic bank Muslim and non-Muslim customers in Malaysia revealed that trust significantly and positively relates to customer loyalty for both customer segments. Reference [9] supported this relationship in an e-banking context. Reference [18]'s investigations on foreign banks customers in Malaysia also provided a supportive evidence. Based on this literature review, it is posited that: customer trust has a positive effect on customer loyalty.

\subsection{Perceived Service Quality and Customer Satisfaction}

Perceived service quality and customer satisfaction relationship in the service industry has received particular consideration among scholars in the literature [19,64,73]. Specifically, several studies advocate this relationship in the banking sector. They include [74] in Indonesia; [19] in Vietnam; [42,68,75] in India; [76] in Rwanda; [13,77,78] in Malaysia; [12] in Sri Lanka; [6] in Pakistan; [9] in Taiwan; [79] in Tanzania. Given the background presented above, this study also assumes that if customers experience poor quality of financial services, they are dissatisfied. Hence, the following hypothesis will be tested: perceived service quality and customer satisfaction are positively related.

\subsection{Trust and Customer Satisfaction}

Although the relationship between trust and customer satisfaction has been studied in different service industries; there seems to be no unanimity on the service quality-customer satisfaction causal order. While several scholars advocate customer satisfaction as a key driver of customer trust $[9,74,80,81,82,83]$; others seem to reverse 
this direction $[27,48,84]$. In this study, it is also agreed that trust leads to customer satisfaction. Prior literature evidenced the role of trust in increasing the degree of customer satisfaction. Reference [84] investigated the effect of trust, commitment and satisfaction on customer loyalty in the distribution sector in Portugal and concluded a positive and direct effect of trust on customer satisfaction. Reference [27]'s study on customers of Travel Agencies in South Sumatra Indonesia also confirmed this relationship. Likewise, [48]'s study in the banking sector of Pakistan provided similar evidence. Based on this literature review, the hypothesis to be tested is: trust is positively associated with customer satisfaction.

\subsection{Customer Satisfaction and Customer Loyalty}

A huge literature has advocated the importance of customer satisfaction in developing customer loyalty in the context of service industry [2,3,11,17,35,63,68,81,82,84,85,86]. According to [25], much a customer is satisfied high is his motivation to patronize the service provider and to recommend him to others. Reference [87] recognizes that highly satisfied customers tend to stick to their current service provider. Reference [84] legitimized a positive influence of customer satisfaction on customer loyalty in the distribution sector in Portugal. Reference [86]'s study provided similar evidence on Air Cargo Terminals in Taiwan. Reference [16] and [11] also found a positive influence of customer satisfaction on customer loyalty in Malaysian banks. In [48]'s study, customer satisfaction has been found to be a major driver of customer loyalty. Reference [67] contrasted this relationship by arguing that a loyal customer may not necessarily be a satisfied customer; [68] and [88] added that a high level of satisfaction does not guarantee customer loyalty. With the support of existing evidences, it is hypothesized that customer satisfaction has a positive effect on customer loyalty.

\subsection{Mediating Effect of Customer Satisfaction in the Relationship between Service Quality, Trust and Customer Loyalty}

Although different studies have supported the intervening role of customer satisfaction in the relationship between service quality and customer loyalty [58,60,73,89]; there is still little known on the extent to which service quality considered alone is sufficient in developing customer loyalty. Reference [60] pointed out the mediating effect of customer satisfaction in the service quality - service loyalty relationship. Reference [73]'s study in telecommunication reported customer satisfaction as an important mediator between perceived service quality and customer loyalty. Reference [90]'s study revealed that better the service quality is, higher customer satisfaction and customer loyalty will be. Likewise, [19]'s analysis showed that customer satisfaction mediates the effects of service quality on customer loyalty.

Some scholars recognize trust as a mediating variable that enhances the effect of customer satisfaction on customer loyalty [85]; studies assessing customer satisfaction in mediating trust and customer loyalty in the banking industry are scarce. Reference [54] found that customer satisfaction intervenes in the relationship between trust and loyalty mobile commerce in Taiwan. Based on these explanations, it is expected that, on the one hand, perceived service quality significantly lead to customer loyalty through the mediating role of customer satisfaction; and on the other hand, customer satisfaction intervenes in the positive relationship between trust and customer loyalty in the context of Bukavu. Hence the following hypotheses: customer satisfaction mediates positive relationships between perceived service quality customer loyalty and trust and customer loyalty.

\section{Methodology}

This study adopted a cross-sectional research design $[4,58,72,85]$ which uses a quantitative method. Data on different variables was gathered at one point in time.

Basing on [91]'s table, considering 95\% confidence level and a margin error of 5\% and using the study population size of 26,557 customers (BCC Report, 2016), the required sample size of 378 respondents were selected and considered for further analysis.

The number of customers investigated from each bank was chosen in proportion of the population size. From each bank, respondents were selected using the convenient sampling method [92]. The study used primary data collected from existing customers of commercial banks in Bukavu using a self-administered questionnaire designed on the basis of prior studies was used.

This study used multi-item scales derived from prior literature. All items were measured on 5-point Likert scales $[6,63,87,93]$ ranging from strongly disagree $(=1)$ to strongly agree (=5). Some items were reverse-coded given their negative impact on the variables.

Perceived service quality was captured by adapting the SERVQUAL instrument from [39] and the BSQ instrument from [43]. Following [41] and [60], the performance-only items was used.

To operationalize trust, the dimensions developed by [46] were adopted with some modifications and supplements.

Customer satisfaction was treated as a uni-dimensional construct and used the items developed by [41].

\section{Analysis and Findings}

\subsection{Survey Response Rate}

378 survey questionnaires were printed and physically distributed to customers of different banks in Bukavu after brief explanations of the research objectives. Data collection process lasted one month. Of these 378 questionnaires, 260 were returned, of which 35 questionnaires were incomplete and/or improperly filled and were thus discarded. Therefore, the analysis was based on 225 fully filled questionnaires representing, $60 \%$ response rate.

The data was collected from customers of seven main banks operating from Bukavu. These were Banque 
Commerciale du Congo, Trust Merchant Bank, Rawbank, Ecobank, FNB Bank, Procredit and Bank of Africa. The majority of the respondents were customers of Rawbank (28.4\%), followed by PROCREDIT (19.6\%), and ECOBANK customers were the minority the sample (8\%).

\subsection{Descriptive Characteristics of the Sample}

Majority of the respondents were male, due to the fact that the majority of bank customers in Bukavu are also male. Women represented only $42.2 \%$ of the respondents.

Regarding the age of the respondents, a descriptive breakdown of the data reveals that most respondents were in the 28-37 age group, followed by those between 18-27 years of age. This indicates that most of the clients surveyed were young. Only a few respondents were 58 years old and above (4\%). The sample contained married respondent in the majority by comparison to singles (32.4\%). Respondents had varied educational backgrounds. Overall, results indicate that the surveyed customers are quite literate. According to the findings, most of the respondents held bachelor degrees (65.3\%) followed by those who held State diplomas (27.6\%). This would indicate that the majority of the respondents were knowledgeable about the research topic handled. Findings also indicate that the respondents had a variety of occupations, from employees in most of the cases (54.7\%), followed by trading business (21.8\%) to students among others.

Years of experience revealed that the majority of the respondents have been banking with their banks for 1 to 5 years, followed by those who have already dealt with their banks for 6 to 10 years. Only $6.7 \%$ of the respondents have been banking with their banks for 11 to 15 years and the rest for 16 to 20 years. Such findings implied that respondents had enough experience and relationship history with their respective banks to be able to objectively evaluate their service performances and provide knowledgeable answers.

\subsection{Factor Analysis}

Exploratory factor analysis (EFA) was performed to reduce the set of items in a smaller number of factors.
KMO index and Bartlett Sphericity test criteria justified the use of EFA.

Reliability analysis was carried out in order to establish the internal consistency of the questionnaire used. The Cronbach's Alpha coefficient for all variables was found to be above 0.7 , indicating that the questionnaire used in this study was reliable [94].

For the variable customer loyalty, three factors were maintained from the initial six dimensions. Behavioral loyalty constituted the main factor of customer loyalty with four items. Results in the table report that this factor was extracted with an eigenvalue of 4.061 and explained $40.606 \%$ of variation in customer loyalty. The second factor extracted (eigenvalue 1.407) was attitudinal loyalty which explained $14.074 \%$ of variance. The last factor cognitive loyalty (eigenvalue 1.012) explained $10.117 \%$ of variance. Overall, the three constructs explained $64.797 \%$ of variance. Results yielded a 4- factors solution (with eigenvalues above 1 ) that accounted for $67.747 \%$ of perceived service quality variance. Hence, these four factors can be considered with some confidence as representing the variable under study. Empathy reported to be the main extracted factor (eigenvalue of 3.628) accounted for $32.977 \%$ of total variance explained. The second factor retained namely Service portfolio (eigenvalue of 1.465) explained $13.319 \%$ of variation in the underlying variable. The last two factors (tangibles and access) accounted for $11.123 \%$ and $10.328 \%$ of variation explained respectively. The unique factor of customer satisfaction presented an eigenvalue of 2.745 and explained $68.62 \%$ of variance. Two factors of Trust presented an eigenvalue above 1 with Integrity being the important factor $(47.391 \%$ of explained variance). Benevolence also accounted for $15.015 \%$. In total, $62.406 \%$ of variation in trust was explained by the two constructs.

Convergent validity was assessed through the average variance extracted (AVE) and composite reliability (CR). Discriminant validity was assessed by comparing correlation coefficients of latent constructs to the square root of average variance extracted [95]. The correlation matrix and square root of AVE are presented in the Table 2.

Table 1. Results of the Exploratory Factor Analysis

\begin{tabular}{|c|c|c|c|c|c|c|}
\hline Variables & Constructs & Variance explained & Eigen-value & AVE & CR & Cron-bach \\
\hline \multirow{4}{*}{ Customer Loyalty } & Behavioral & 40.606 & 4.06 & 0.528 & 0.82 & \multirow{4}{*}{0.868} \\
\hline & Attitudinal & 14.074 & 1.41 & 0.788 & 0.81 & \\
\hline & Cognitive loyalty & 10.117 & 1.01 & 0.768 & 0.81 & \\
\hline & Total & 64.797 & & & & \\
\hline \multirow{5}{*}{ Perceived Service quality } & Empathy & 32.977 & 3.63 & 0.581 & 0.85 & \multirow{5}{*}{0.920} \\
\hline & Service Portfolio & 13.319 & 1.47 & 0.570 & 0.81 & \\
\hline & Tangibles & 11.123 & 1.22 & 0.708 & 0.83 & \\
\hline & Access & 10.328 & 1.14 & 0.638 & 0.78 & \\
\hline & Total & 67.747 & & & & \\
\hline \multirow{2}{*}{ Customer Satisfaction } & Customer satisfaction & 68.620 & 2.75 & 0.686 & 0.90 & \multirow{2}{*}{0.842} \\
\hline & Total & 68.620 & & & & \\
\hline \multirow{3}{*}{ Trust } & Integrity & 47.391 & 3.79 & 0.587 & 0.85 & \multirow{3}{*}{0.871} \\
\hline & Benevolence & 15.015 & 1.20 & 0.544 & 0.83 & \\
\hline & Total & 62.406 & & & & \\
\hline
\end{tabular}


Table 2. Correlation between Constructs and Square root of Average Variance Extracted

\begin{tabular}{|c|c|c|c|c|c|c|c|c|c|c|}
\hline & $\mathrm{BE}$ & $\mathrm{AT}$ & $\mathrm{CO}$ & EMP & TAN & ACC & SP & CS & INT & BEN \\
\hline $\mathrm{BE}$ & .727 & & & & & & & & & \\
\hline $\mathrm{AT}$ & $.382^{* *}$ & .888 & & & & & & & & \\
\hline $\mathrm{CO}$ & $.474^{* *}$ & $.493^{* * *}$ & .876 & & & & & & & \\
\hline EMP & $.489^{* *}$ & $.400^{* *}$ & $.512^{* *}$ & .762 & & & & & & \\
\hline TAN & $.327^{* *}$ & .091 & $.209^{* *}$ & $.291^{* *}$ & .841 & & & & & \\
\hline ACC & .105 & .104 & $.186^{* *}$ & $.135^{*}$ & $.131^{*}$ & .799 & & & & \\
\hline SP & $.300^{* *}$ & $.246^{* *}$ & $.360^{* *}$ & $.434^{* * *}$ & $.325^{* *}$ & $.227^{* *}$ & .755 & & & \\
\hline CS & $.572^{* *}$ & $.442^{* *}$ & $.590^{* * *}$ & $.689^{* *}$ & $.442^{* *}$ & $.193^{* *}$ & $.530^{* *}$ & .828 & & \\
\hline INT & $.458^{* *}$ & $.338^{* *}$ & $.456^{* *}$ & $.660^{* *}$ & $.309^{* * *}$ & .046 & $.354^{* *}$ & $.727^{* *}$ & .766 & \\
\hline BEN & $.378^{* *}$ & $.434^{* *}$ & $.469^{* *}$ & $.683^{* *}$ & $.238^{* *}$ & $.185^{* *}$ & $.395^{* *}$ & $.620^{* *}$ & $.534^{* *}$ & .738 \\
\hline
\end{tabular}

Table 2 provides information on the correlation coefficients between latent constructs with their significance level and the square root of AVE (bold typed in the diagonal). Evidences from Table 1-Table 2 revealed that AVE values exceeded the minimum recommended cut-off of $0.5[63,96]$ and the CR for all constructs were above 0.7 [97]. The combined information from composite reliability (CR) and AVE values indicate adequate convergent validity of the measurements. In assessing discriminant validity, results from Table 2 show that all the square root of AVE are equal or above the coefficients of correlation between latent constructs to signify the difference between retained constructs [97].

\subsection{Descriptive Statistics}

The descriptive statistics of the study variables presented here include the minimum, the maximum, the mean, the standard deviation and the coefficient of variation. The summary of the descriptive statistics of different variables measured on a 5-point Likert scale is presented in Table 3.

Table 3. Summary of the Descriptive Statistics

\begin{tabular}{|c|c|c|c|c|c|c|c|c|}
\hline \multirow{2}{*}{ Vari-ables } & \multicolumn{2}{|c|}{ Min } & \multicolumn{2}{c|}{ Max } & \multicolumn{2}{c|}{ Mean } & \multicolumn{2}{c|}{$\begin{array}{c}\text { Std. } \\
\text { Deviation }\end{array}$} \\
\cline { 2 - 9 } & Score & $\%$ & Score & $\%$ & Score & $\%$ & Score & $\%$ \\
\hline CS & 1.00 & 0.0 & 5.00 & 100.0 & 3.64 & 66.0 & 0.79 & 19.7 \\
\hline CL & 1.49 & 12.2 & 4.56 & 88.9 & 3.25 & 56.3 & 0.62 & 15.6 \\
\hline PSQ & 1.90 & 22.5 & 4.88 & 97.0 & 3.57 & 64.3 & 0.49 & 12.3 \\
\hline TR & 2.00 & 25.0 & 4.88 & 96.9 & 3.63 & 65.9 & 0.61 & 15.3 \\
\hline
\end{tabular}

The minimum scores reported in Table 3 reveal that the less satisfied customer was totally dissatisfied (0.0) while the most satisfied totally satisfied; that the less loyal customers exhibited $12.2 \%$ of loyalty to their banks whereas the most were $88.9 \%$ loyal; $22.5 \%$ was the lowest quality of the services perceived by the respondents while the best quality perceived was $97.0 \%$ high. Finally the less trustworthy bank service provider in Bukavu was judged to be trustworthy at $25 \%$ whereas the most trustworthy was $96.4 \%$ trustworthy.
These findings also reveal that the mean score of customer satisfaction (3.642) is greater than 3, the midpoint of the used scale (neither agree nor disagree) and provides a standard deviation of 0.789 . This indicates that customers of banks in Bukavu are relatively satisfied and there is some homogeneity in their satisfaction. The mean score of customer loyalty is 3.253 which represents about $56.3 \%$ and implies that the customers of Bukavu exhibit a low level of loyalty to their respective bank service providers with a low dispersion around the mean (std. deviation of 0.623). For the variable perceived service quality, the mean score is also relatively high (3.570) to suggest that customers perceive the quality of the services being offered by the banks to be relatively high with some homogeneity (std. deviation of 0.492). Lastly, the mean score of trust is 3.634 (65.85\%) with a standard deviation of 0.611 , indicating that the customers find the different banks of Bukavu relatively trustworthy, and with low discrepancy among respondents’ answers.

Thus, overall the study variables exhibit low dispersion (standard deviation) to indicate low data spread around the means and homogeneity among respondents' answers.

\subsection{Relationship between Variables: Correlation Analysis}

Recall that this study investigates the relationships between perceived service quality, trust, customer satisfaction and customer loyalty the banking sector of Bukavu. To examine the strength of these relationships between the study variables, the coefficients of correlation were computed. The correlation matrix is presented in the following table.

Table 4. Correlation Matrix between the Study Variables

\begin{tabular}{|l|c|c|c|c|c|c|}
\hline & 1 & 2 & 3 & 4 & 5 & 6 \\
\hline CS (1) & 1 & & & & & \\
\hline PSQ (2) & $.680^{* *}$ & 1 & & & & \\
\hline CL (3) & $.661^{* *}$ & $.504^{* *}$ & 1 & & & \\
\hline TR (4) & $.767^{* *}$ & $.602^{* *}$ & $.601^{* *}$ & 1 & & \\
\hline Age (5) & -.001 & -.021 & -.023 & .029 & 1 & \\
\hline Experience (6) & -.072 & -.060 & -.058 & -.042 & $.257^{* *}$ & 1 \\
\hline
\end{tabular}


Table 4 presents a correlation matrix for the study variables. The implementation procedure has been subject to two tailed tests at two different levels of significance (0.01 and 0.05).

Findings reveal a strong positive relationship between perceived service quality and customer satisfaction $(\mathrm{r}=.680, \mathrm{p}<0.01)$. This implies that high perceived quality of a bank service is associated to high level of satisfaction, in other words, customers are very satisfied when they feel that the services performed by the bank meet or exceed their expectations.

Perceived service quality is positively and significantly $(r=.504, p<0.01)$ related to customer loyalty to signify that the higher the quality of services is perceived by customers, the more customers become loyal.

There is a positive and significant relationship between trust and customer satisfaction $(\mathrm{r}=.767, \mathrm{p}<0.01)$ indicating that customer satisfaction increases with the amount of trust customers have in the bank.

Trust was found to be significantly and positively correlated with customer loyalty $(r=.601, \mathrm{p}<0.01)$ to imply that when customers judge a bank as being more trustworthy, they tend to be more loyal to that particular bank.

Customer satisfaction is positively and significantly correlated with customer loyalty $(\mathrm{r}=0.661, \mathrm{p}<0.01)$ to indicate that satisfied customers will patronize the bank for their future needs. In a coherent manner, more satisfied a customer is, very loyal he tends to be towards the bank providing him satisfaction.

Globally, results presented in the table supported the hypothesized relationships among the study variables with high statistical significance.

The correlation matrix presents also correlation coefficients of other control variables. No significant relationships were found between respondents' age and the study variables. Respondents' education level was found to be negatively and significantly related to customer satisfaction $(r=-0.135, \mathrm{p}<0.05)$ and to customer trust $(\mathrm{r}=-0.139, \mathrm{p}<0.05)$ to signify that respondents with high education levels are the less satisfied and lack trust in their respective banks. Experience with the bank has no significant relationship with the study variables.

\subsection{Hierarchical Regression Models}

Hierarchical regression analysis [30,58] was used to examine the contributions of perceived service quality, trust and customer satisfaction to change in customer loyalty. The table below summarizes the results of the regressions.

Model 1 in the above table focuses on analyzing the effect of control variables (gender of the respondents, age, marital status, higher level of education, main occupation and experience in business with the bank). Findings in model 1 revealed that only the main occupation was a statistically significant predictor of bank customer loyalty $(\beta=.207 ; t=3.070 ; p=0.00)$. It contributed positively to customer loyalty. Other variables gender, age, marital status, education and experience with the bank (with $\mathrm{t}<$ 1.96; $p>0.05)$ ) were not statistically significant predictors of bank customer loyalty. The model 1 indicated that 5.7 percent of variance was explained by the main occupation and the overall goodness of fit reported that the model is significant $(F=2.186 ; p=0.046)$.

Perceived service quality has been introduced in Model 2. Among the control variables, it is gender $(\beta=.131 ; t=2.197 ; p=0.029)$ and main occupation $(\beta=.176 ; t=3.006 ; p=0.003)$ which are now statistically significant to imply that they have a positive relationship with customer loyalty.

Introduction of perceived service quality, variable which is also statistically significant $(\beta=.494 ; \mathrm{t}=8.566 ; \mathrm{p}$ $=0.000$ ) and hence has positive effect on customer loyalty, has improved the variance explained by model by 24.1 percent, giving 29.8 percent. The model is generally very significant given its goodness of fit.

Table 5. Summary of the Hierarchical Regressions

\begin{tabular}{|c|c|c|c|c|c|c|c|c|c|c|c|c|}
\hline \multirow{2}{*}{ IV } & \multicolumn{3}{|c|}{ Model 1} & \multicolumn{3}{|c|}{ Model 2} & \multicolumn{3}{|c|}{ Model 3} & \multicolumn{3}{|c|}{ Model 4} \\
\hline & B & $\mathrm{T}$ & Sig & B & $\mathrm{T}$ & Sig & B & $\mathrm{T}$ & Sig & $\beta$ & $\mathrm{T}$ & Sig \\
\hline Gender & .105 & 1.521 & .130 & .131 & 2.197 & .029 & .126 & 2.336 & .020 & . 133 & 2.604 & .010 \\
\hline Age & .022 & .290 & .772 & .014 & .213 & .832 & .011 & .176 & .860 & .008 & .133 & .894 \\
\hline Marital status & -.059 & -.744 & .458 & -.043 & -.618 & .537 & -.098 & -1.561 & . 120 & -.094 & -1.586 & .114 \\
\hline Education & -.049 & -.732 & .465 & -.018 & -.302 & .763 & .036 & .677 & .499 & .061 & 1.206 & .229 \\
\hline Occupation & .207 & 3.070 & .002 & . 176 & 3.006 & .003 & .125 & 2.353 & .020 & .086 & 1.672 & .096 \\
\hline Experience & -.044 & -.630 & .530 & -.020 & -.328 & .743 & -.001 & -.026 & .980 & .007 & .139 & .889 \\
\hline PSQ & & & & .494 & 8.566 & .000 & .215 & 3.292 & .001 & .070 & 1.021 & .308 \\
\hline TR & & & & & & & .469 & 7.048 & .000 & .236 & 3.007 & .003 \\
\hline CS & & & & & & & & & & .428 & 4.995 & .000 \\
\hline R square & .057 & & & .298 & & & .431 & & & .491 & & \\
\hline Change in $\mathrm{R}^{2}$ & & & & .241 & & & .133 & & & .060 & & \\
\hline Adjusted R² & .031 & & & .275 & & & .410 & & & .469 & & \\
\hline$F$ & 2.186 & & & 12.986 & & & 20.158 & & & 22.705 & & \\
\hline Sig. (F) & .046 & & & .000 & & & .000 & & & .000 & & \\
\hline
\end{tabular}


Results of model 3 reveal that the variable trust has been introduced in the model. The two control variables have remained significant at 5 percent level of significance. They both report positive relationships $(\beta=.126 ; t=2.336 ; p=0.020$ for gender and $\beta=.125 ; t=$ 2.353; $p=0.020$ for occupation) with customer loyalty. This implies that the fact of being male or female leads to variations in customer loyalty. Findings revealed that five respondents' main occupations (trading business, employees, farmers, entrepreneurs and others). Pertaining to one or another of these occupation categories does significantly have impact on the level of customer loyalty. Perceived service quality $(\beta=.215 ; t=3.292 ; p=0.001)$ and trust $(\beta=.469 ; t=7.048 ; p=0.000)$ have been found to have positive effects on customer loyalty. Such results imply that an increase in the service quality perceived by customers and an improvement in the level of trust are favorable to building very loyal customer basis. The $\mathrm{R}$ Square indicates that 43.1 percent of variation in customer loyalty is explained by the independent variables (an incremental increase of 13.3 percent compared to the one in model 2) and the model fit is acceptable ( $F=20.158$; $\mathrm{p}=.000)$.

In model 4, customer satisfaction was introduced. Only gender $(\beta=.133 ; \mathrm{t}=2.604 ; \mathrm{p}=0.010)$ remained statistically significant at 5 percent to imply that the level of loyalty varies as customers are male or female. Results reveal that perceived service quality has a positive but not significant predictive $(\beta=.070 ; t=1.021 ; p=0.308)$ effect on customer loyalty. The significant and positive effect $(\beta=.236 ; t=3.007 ; p=0.003)$ of trust has reduced in this model due to the introduction of customer satisfaction in the model. Customer satisfaction has also been found to be positively and significantly related to customer loyalty $(\beta=.428 ; t=4.995 ; p=0.000)$. The overall goodness of fit of the model has improved $(F=22.705, p=0.000)$ with 49.1 percent of variance in customer loyalty explained by the model.

\subsection{The Mediating Role of Customer Satisfaction (Indirect Effect)}

Following Baron and Kenny (1986) as inspired in recent literature [98,99], the study used a series of regression models to assess the mediating role of customer satisfaction in the relationships between perceived service quality and customer loyalty and trust and customer loyalty. This was done in three steps. First, the independent variable (perceived service quality/trust) was regressed on the dependent variable (customer loyalty) to check the existence of an effect that could be mediated. In the next step, the mediating variable (customer satisfaction) was regressed on the independent variable, considering the mediator as the dependent variable. Lastly, the dependent variable (customer loyalty) was regressed on both the independent and mediating variables. Results are presented in Table 6 and Table 7.

Model 1 in Table 6 shows that there is a strongly significant and positive effect of perceived service quality on customer loyalty $(\beta=0.504 ; t=8.712 ; p=0.000)$. The adjusted $\mathrm{R}$ Square of 0.251 indicates that $25.1 \%$ of variation in customer loyalty is explained by perceived service quality. The model fit results indicate that the model as a whole is significant $(\mathrm{F}=75.901, \mathrm{p}=0.000)$. Therefore, perceived service quality contributes positively and significantly to customer loyalty. Results from model 2 indicate that perceived service quality is positively and significantly related to customer satisfaction $(\beta=0.680$; $\mathrm{t}=13.854 ; \mathrm{p}=0.000)$. Overall, perceived service quality explains $46.0 \%$ of variance in customer satisfaction and is significant $(\mathrm{F}=191.931, \mathrm{p}=0.000)$. Results of model 3 reveal that there is no significant relationship between perceived service quality and customer loyalty $(\beta=0.101$; $\mathrm{t}=1.483$; $\mathrm{p}=0.140$ ) but there is a positive and significant relationship between customer satisfaction and customer loyalty $(\beta=0.592 ; t=8.656 ; p=0.000)$. The percentage of variance in customer loyalty explained by the model is $44.2 \%$ (with $\mathrm{F}=87.999, \mathrm{p}=000$ ). Notice that perceived service quality was significant in both models 1 and 2 and that customer satisfaction was significant in model 3 . $\beta$ coefficient of perceived service quality is no longer significant (in model 3) due to the introduction of the customer satisfaction variable to imply that the total effect of perceived service quality on customer loyalty has been canalized through customer satisfaction; hence there is complete mediation.

Model 1 reports a strongly significant and positive effect of trust on customer loyalty $(\beta=0.601$; $t=11.242$; $\mathrm{p}=0.000)$, confirming what was revealed through correlation analysis. R Square of .362 indicates that $36.2 \%$ of variation in customer loyalty is explained by customer trust. The overall goodness of fit of the model is acceptable $(\mathrm{F}=25.054, \mathrm{p}=0.000)$.

Model 2 indicates that trust has also a positive and significant effect on customer satisfaction $(\beta=0.767$; $\mathrm{t}=17.878 ; \mathrm{p}=0.000)$. Overall, trust explains $58.9 \%$ of variance in customer satisfaction and is significant $(\mathrm{F}=319.605, \mathrm{p}=0.000)$. Model 3 reveals a significant and positive relationship between trust and customer loyalty $(\beta=0.229 ; \mathrm{t}=2.978 ; \mathrm{p}=0.000)$ and a positive and significant relationship between customer satisfaction and customer loyalty $(\beta=0.485 ; t=6.291 ; p=0.000)$. The percentage of variance in customer loyalty explained by the model is 45.8 percent (with $\mathrm{F}=93.917$, $\mathrm{p}=000$ ).

Table 6. Testing the Mediating Role of Customer Satisfaction in the Relationship between Perceived Service Quality and Customer Loyalty

\begin{tabular}{|c|c|c|c|}
\hline Variablec & Customer Loyalty & Customer Satisfaction & Customer Loyalty \\
\hline vallables & Model 1 & Model 2 & Model 3 \\
\hline PSQ & $.504(8.712)^{* * *}$ & $.680(13.854)^{* * *}$ & $.101(1.483)$ \\
\hline CS & & & $.592(8.656)^{* * *}$ \\
\hline $\mathrm{F}$ & $75.901 * * *$ & $191.931^{* * *}$ & $87.999 * * *$ \\
\hline $\mathrm{R}^{2}$ & .254 & .463 & .442 \\
\hline Adjusted $\mathrm{R}^{2}$ & .251 & .460 & .437 \\
\hline
\end{tabular}


Table 7. Testing the Mediating Role of Customer Satisfaction in the Relationship between Trust and Customer Loyalty

\begin{tabular}{|cccc|}
\hline Variables & Customer loyalty & Customer satisfaction & Customer loyalty \\
& Model 1 & Model 2 & Model 3 \\
TR & $0.601(11.242)^{* * *}$ & $0.767(17.878)^{* * *}$ & $0.229(2.978) * * *$ \\
CS & & & $0.485(6.291)^{* * *}$ \\
F & $126.391^{* * *}$ & $319.605^{* * *}$ & $93.917 * *$ \\
$\mathrm{R}^{2}$ & .362 & .589 & .458 \\
Adjusted $\mathrm{R}^{2}$ & .359 & .587 & .453 \\
\hline
\end{tabular}

$* * * \mathrm{p}<0.01 ;()=.\mathrm{t}$ values.

Evidence from the table reports that trust was significant in both models 1 and 2 and that customer satisfaction was significant in model 3. The $\beta$ coefficient of trust has decreased (in model 3) when the customer satisfaction was introduced to imply that part effect of trust on customer loyalty was channeled through customer satisfaction to produce a partial mediation. Total effect of trust (0.601) on customer loyalty is a result, on the one hand, of a direct effect of 0.229 and, on the other hand, an indirect effect of $0.372(0.485 * 0.767)$.

Therefore, the hypothesis (6) according to which customer satisfaction positively mediates the relationship between perceived service quality, trust and customer loyalty was supported.

\section{Discussion}

Perceived service quality is well documented as an important ingredient of customer loyalty. Numerous prior studies supported a positive relationship between perceived service quality and customer loyalty in the banking industry $[1,4,8,11,13,16,19,38,66,67,68,69]$. For instance, the [16]'s study concluded that chances are high that a customer satisfied with a bank service quality favor the bank and be continuously loyal to it. However, this finding was inconsistent with [100] who found that perceived service quality was not significantly related to customer loyalty for customers using internet banking website in Malaysia.

Results revealed that trust was a significant factor that bank customers look for in Bukavu in order to be loyal to their respective banks. This was consistent with [18] who contended that strong customer trust towards the service provider builds confidence and enables prediction of future service providers' actions thereby influencing customer loyalty. This result is also consistent with previous studies [27,30,71,72] that pointed to a positive relationship between trust and customer loyalty in the service industry in general and in others industries $[16,17,18,24]$. This further underlined the role of trust in developing customer loyalty in a risky and very uncertain environment such as the banking sector. Reference [16] posited that trust is important for improving customer loyalty as customers who trust their banks are less likely to switch to competitors. However, these results are contrasted by [101] who found a negative relationship in banks in South Thailand.

Perceived service quality was revealed to have a direct great effect on the degree to which bank customers are satisfied. Prior studies [19,75,76,79,101] propounded this effect in the banking sector as well. Reference [13] supported this relationship in Malaysian commercial banking industry.

There was a support for the positive relationship between trust and customer satisfaction, this, in accordance with previous studies. The study conducted by [48] in the banking sector of Pakistan supported this finding by positing that for a trustworthy service performance naturally satisfies a customer. Likewise, it is also in agreement with [102] who found in trust an important source of satisfaction.

Results revealed that bank customers in Bukavu tend to stick to the same bank once they are satisfied. Prior studies supported this relationship [19]. Reference [8] found that customer satisfaction was one of the major determinants of customer loyalty in Sub-Saharan African Banking industry. Likewise, [13] considered customer satisfaction as the most direct and important predictor of customer loyalty. Also [86]'s study concluded that high customer satisfaction leads to their inclination to remain loyal. However, these results are contrasted by [67] who argued that customer loyalty customer is not necessarily a result of customer satisfaction. Similarly, [68] and [88] opposed this relationship by arguing that there is no guarantee of customer loyalty in a high level of satisfaction.

There was a complete mediation of customer satisfaction in the relationship between perceived service quality and customer loyalty, implying that all the effect of perceived service quality on customer loyalty was channeled through customer satisfaction. This was well supported by previous studies [13,60,73,89]. Reference [13] found that customer satisfaction significantly mediated the relationship between perceived service quality and customer loyalty. Unlike this finding, [19] viewed customer satisfaction as partially mediating the relationship between perceived service quality and customer loyalty.

Customer satisfaction partially mediates trust and customer loyalty relationship. In other words, much effect of trust on customer loyalty was channeled through customer satisfaction implying that customer loyalty was significantly affected by customer trust where customer satisfaction plays a strong mediating role. This is in agreement with [54] in a mobile commerce context in Taiwan. Studies examining customer satisfaction in mediation of trust and customer loyalty are still scarce in the banking sector. This constitutes one of the first attempts in the context of Bukavu. 


\section{Conclusion}

Customer loyalty is an asset of paramount importance to a bank. Reference [87] indicated that loyal customers assure the sustainability of the company's life. This study extended the current existing body of knowledge related to the study of customer loyalty in the banking sector in the context of Bukavu (East of DRC). Findings revealed that perceived service quality, trust and customer satisfaction are important predictors of customer loyalty. About 49.1\% of variation in customer loyalty is explained by the studied variables. The research findings led to the support of all the research hypotheses and corroborated previous studies. Mean score results revealed that on average, bank customers in Bukavu perceive a relatively high quality (3.570) of services they enjoy, their level of trust towards the financial service providers is relatively high (3.634), and they are on average slightly satisfied (3.642). Consequently, they are moderately loyal (3.253) to their respective banks. Results also revealed that customer satisfaction plays a mediating role between perceived service quality and customer loyalty relationship and between trust and customer loyalty.

Based on the research findings and drawn conclusions, the following recommendations were formulated. Perceived service quality was found to be an important antecedent of customer loyalty for banks operating in Bukavu. The study, therefore, recommends regular talks between banks and their customers as to well internalize their needs and design services accordingly; customer satisfaction and loyalty should regularly be assessed. Banks in the DRC need to integrate ethical values in their regular communications with customers in order to instill trust. Bank managers should design a very well diversified service and product portfolio consistent with the latest technology to meet the variety of customer needs and widen the channels in order to reach all customers (set new branches, ATM in new locations, mobile and online banking).

Findings and results of this study are to retain with a number of limitations in mind. Loyalty is a temporary behavior. A customer may be loyal today and changes his behavior tomorrow. Given that fact, the results of this study should be used cautiously. Since customer relationships are built over time [85]; gathering data at one point in time cannot fully capture the dynamic nature of different variables studied. Therefore, measuring these variables over a certain period would lead to meaningful results. Moreover, the current study did not include all the variables that affect customer loyalty towards banks in Bukavu. Introduction of new variables would improve the explained variance.

Furthermore, perceived service quality was measured by performance-only scale. This probably affected results and findings. Other studies could adopt the gap scores approach while measuring service quality; this would provide different results.

\section{Acknowledgements}

The authors are particularly grateful to the anonymous reviewers for their valuable comments as well as to the
Université Evangélique en Afrique (UEA/ Bukavu) for its unconditional financial support.

\section{References}

[1] B. Afsar, Z. U. Rehman, J. A. Qureshi, and A. Shahjehan, "Determinants of customer loyalty in the banking sector: The case of Pakistan,” African J. Bus. Manag., vol. 4, no. 6, pp. 1040-1047, 2010.

[2] I. Ali, A. K. Alvi, and R. R. Ali, "Corporate reputation, consumer satisfaction and loyalty," Rom. Rev. Soc. Scienes, vol. 3, pp. 13-23, 2012.

[3] A. Chochol’áková, L. Gabcová, J. Belás, and J. Sipko, "Bank customers' satisfaction, customers' loyalty and additional purchases of banking products and services. A case study from the Czech Republic,” Econ. Sociol., vol. 8, no. 3, pp. 82-94, 2015.

[4] D. O. Auka, J. N. Bosire, and V. Matern, "Perceived service quality and customer loyalty in retail banking in Kenya," Br. $J$. Mark. Stud., vol. 1, no. 3, pp. 32-61, 2013.

[5] Y. Köksal and O. Dema, "An investigation of the issential factors on customer loyalty in banking sector: a case of Albanian retail bank,” Yönetim ve Ekon., vol. 21, no. 1, pp. 357-368, 2014.

[6] M. Zafar, S. Zafar, A. Asif, A. I. Hunjra, and H. M. Ahmad, "Service quality, customer satisfaction and loyalty: an empirical analysis of banking sector in Pakistan," Inf. Manag. Bus. Rev., vol. 4, no. 3, pp. 159-167, 2012.

[7] N. Joshi, "SERVLOYAL amongst bank customers of Indore: an exploratory research," in International Conference on Business, Economics, Management and Bahavioral Sciences, 2012, pp. 573-577.

[8] C. Magasi, "Determinants of customer loyalty in sub-Saharan African banking industry: an empirical review," Int. J. Econ. Commer. Manag., vol. IV, no. 2, pp. 574-588, 2016.

[9] P.-Y. Chu, G.-Y. Lee, and Y. Chao, "Service quality, customer satisfaction, customer trust, and loyalty in an E-banking context," Soc. Behav. Pers., vol. 40, no. 8, pp. 1271-1284, 2012.

[10] A. Parasuraman, V. A. Zeithaml, and L. L. Berry, "A conceptual model of service quality and its implication for future research," J. Mark., no. January, 1985.

[11] Z. Osman, L. Mohamad, and R. K. Mohamad, "An empirical study of direct relationship of service quality, customer satisfaction and bank image on customer loyalty in Malaysian commercial banking industry,” Am. J. Econ. 2015, vol. 5, no. 2, pp. 168-176, 2015.

[12] J. J. Navaratnaseelana and P. Elangkumaran, "Impact of service quality on customer satisfaction: a study on customers of commercial bank of Ceylon PLC Trincomalee District,” in Oral Presentations, 2014, pp. 359-364.

[13] Z. Osman and I. Sentosa, "Influence of customer satisfaction on service quality and customer loyalty relationship in Malaysian commercial banking industry," Int. J. Econ. Financ. Manag., vol. 3, no. 2, pp. 115-120, 2014.

[14] E. Garbarino and M. S. Johnson, "The Different roles of satisfaction, trust, and commitment in customer relationships," $J$. Mark., vol. 63, no. 2, pp. 70-87, 1999.

[15] A. Suvittawat, "Commercial bank service quality: Chonburi Province, Thailand,” Int. J. Manag. Sci. Bus. Res., vol. 4, no. 2, pp. 13-17, 2015.

[16] S. Lee and S. Moghavvemi, "The dimension of service quality and its impact on customer satisfaction, trust, and loyalty: a case of Malaysian banks,” Asian J. Bus. Account., vol. 8, no. 2, pp. 91-122, 2015.

[17] M. Amin, Z. Isa, and R. Fontaine, "Islamic banks, contrasting the drivers of customer satisfaction on image, trust, and loyalty of Muslim and non-Muslim customers in Malaysia,” Int. J. Bank Mark., vol. 31, no. 2, pp. 79-97, 2013.

[18] H. Hasan, T. P. Kiong, and R. A. Ainuddin, "Effects of perceived value and trust on customer loyalty towards foreign banks in Sabah, Malaysia," Glob. J. Emerg. Trends e-Business, Mark. Consum. Psychol., vol. 1, no. 2, pp. 137-153, 2014.

[19] N. V. Minh and N. H. Huu, "The relationship between service quality, customer satisfaction and customer loyalty: an investigation in Vietnamese retail banking sector," J. Compet., vol. 8, no. 2, pp. 103-116, 2016. 
[20] TMB, “Annual Report 2015,” Kinshasa, 2015.

[21] KPMG, "Africa banking industry, retail customer satisfaction survey," 2016.

[22] L. Gilman, A. Genova, and M. Kaffenberger, "Mobile money in the Democratic Republic of Congo: market insights on consumer needs and opportunities in payments and financial services," 2013.

[23] J. Mwema, "Sud-Kivu: par manque de confiance dand les IMF, la population préfère garder son argent à l'étranger," Echos de l'Evangile Magazine, Bukavu, 2018.

[24] S. Mukherjee, "Antecedents and impact of consumer trust in business to business markets," Amity J. Mark., vol. 1, no. 1, pp. 41-58, 2016.

[25] S. Y. Lam, V. Shankar, M. K. Erramilli, and B. Murthy, "Customer value, satisfaction, loyalty, and switching costs: An illustration from a business-to-business service context," J. Acad. Mark. Sci., vol. 32, no. 3, pp. 293-311, 2004.

[26] V. A. Zeithaml, L. L. Berry, and A. Parasuraman, "The behavioral consequences of service quality,” J. Mark., vol. 60, no. 2, pp. 31-46, 1996.

[27] H. Setiawan and A. J. Sayuti, "Effects of service quality, customer trust and corporate image on customer satisfaction and loyalty: an assessment of travel agencies customer in South Sumatra Indonesia,” IOSR J. Bus. Manag., vol. 19, no. 05, pp. 31-40, 2017.

[28] J. C. Sudhahar, D. Israel, A. P. Britto, and M. Selvam, "Service loyalty measurement scale: A reliability assessment,” Am. J. Appl. Sci., vol. 3, no. 4, pp. 1814-1818, 2006.

[29] S. Utami, "The onfluence of customer trust on customer loyalty," Int. J. Econ. Commer. Manag., vol. III, no. 7, pp. 638-653, 2015.

[30] N. K. Upamannyu, C. Gulati, A. Chack, and G. Kaur, "The effect of customer trust on customer loyalty and repurchase intention: the moderating influence of perceived CSR,” Int. J. Res. IT, Manag. Eng., vol. 5, no. 4, pp. 1-31, 2015.

[31] Z. Yang and R. T. Peterson, "Customer perceived value, satisfaction, and loyalty: the role of switching costs," Psychol. Mark., vol. 21, no. 10, pp. 799-822, 2004.

[32] C. Grönroos, "A service quality model and its marketing implications,” Eur. J. Mark., vol. 18, no. 4, pp. 36-44, 1984.

[33] A. Shahin and M. Samea, "Developing the models of service quality gaps: a critical discussion,” Bus. Manag. Strateg., vol. 1, no. 1 , pp. 1-11, 2010

[34] G. Kang and J. James, "Service quality dimensions: an examination of Gronroos' service quality model,” J. Serv. Theory Pract., vol. 14, no. 4, pp. 266-277, 2004.

[35] M. M. Lau, R. Cheung, A. Y. C. Lam, and Y. T. Chu, "Measuring service quality in the banking industry: a Hong Kong based study," Contemp. Manag. Res., vol. 9, no. 3, pp. 263-282, 2013.

[36] G. M. Aboul-Ela, "Analyzing the antecedents of customer loyalty," Br. J. Mark. Stud., vol. 3, no. 5, pp. 34-48, 2015.

[37] A. Salim, M. Setiawan, Rofiaty, and F. Rohman, "How to build satisfaction and customer loyalty with a focus on complaints handling (Review of the scientific literature)," J. Financ. Bank. Rev., vol. 2, no. 2, pp. 28-33, 2017.

[38] C. D. Tinashe and C. Eustina, "The impact of customer retention strategies on customer loyalty and satisfaction in Zimbabwean commercial banks (2014-2015)," Case Stud. J., vol. 5, no. 11, pp. 5-12, 2016

[39] A. Parasuraman, V. A. Zeithaml, and L. L. Berry, "Servqual: a multiple-item scale for measuring consumer perceptions of service quality,” J. Retail., vol. 64, no. 1, pp. 12-40, 1988.

[40] W. M. Lassar, C. Manolis, and R. D. Winsor, "Service quality perspectives and satisfaction in private banking," J. Serv. Mark., vol. 14, no. 3, pp. 244-271, 2000.

[41] R. Ladhari, I. Ladhari, and M. Morales, "Bank service quality: comparing Canadian and Tunisian customer perceptions," Int. J. Bank Mark., vol. 29, no. 3, pp. 224-246, 2010.

[42] N. Ragavan and R. Mageh, "A study on service quality perspectives and customer satisfaction in new private sector banks," J. Bus. Manag., vol. 7, no. 2, pp. 26-33, 2013.

[43] K. Bahia and J. Nantel, "A reliable and valid measurement scale for the perceived service quality of banks," Int. J. Bank Mark., vol. 18, no. 2, pp. 84-91, 2000.

[44] J. J. Cronin and S. A. Taylor, "Measuring service quality: a reexamination and extension,” J. Mark., vol. 56, no. 3, p. 55, 1992.

[45] R. M. Morgan and S. D. Hunt, "The commitment-trust theory of relationship marketing,” J. Mark., vol. 58, pp. 20-38, 1994.
[46] P. M. Doney and J. P. Cannon, "An examination of the nature of trust in buyer-seller relationships,” J. Mark., vol. 61, no. 2, p. 35, 1997.

[47] S. P. Gounaris, "Trust and commitment influences on customer retention: insights from business-to-business services,” J. Bus. Res., vol. 58, pp. 126-140, 2005.

[48] R. Gul, "The relationship between Reputation, customer satisfaction, trust, and loyalty,” J. Public Adm. Gov., vol. 4, no. 3, pp. 368-387, 2014.

[49] A. Mukherjee and P. Nath, "A model of trust in online relationship banking,” Int. J. Bank Mark., vol. 21, no. 1, pp. 5-15, 2003.

[50] A. M. Ben Jemaa and N. Tournois, "Toward a trustful B to B relationship,” Int. J. Bus. Manag., vol. 4, no. 10, pp. 64-77, 2009.

[51] K. K. Kooli, K. Ben Mansour, R. Utama, K. Ben, and R. Utama, "Determinants of online trust and their impact on online purchase intention,” Int. J. Technol. Mark., vol. 9, no. 3, pp. 1-19, 2014.

[52] R. Kantsperger and W. H. Kunz, "Consumer Trust in Service Companies: a Multiple Mediating Analysis,” pp. 1-35.

[53] S. Pandey and S. Srivastava, "Antecedents of customer purchase intention,” IOSR J. Bus. Manag., vol. 18, no. 10, pp. 55-82, 2016.

[54] H. Lin and Y. Wang, "An examination of the determinants of customer loyalty in mobile commerce contexts," Inf. Manag., vol. 43, pp. 271-282, 2006.

[55] B. Cater, "Trust and commitment in professional business-tobusiness markets," Manag. Glob. Transitions, vol. 5, no. 4, pp. 371-390, 2007.

[56] N. Nguyen, A. Leclerc, and G. Leblanc, "The mediating role of customer trust on customer loyalty,” J. Serv. Sci. Manag., vol. 6, pp. 96-109, 2013.

[57] P. C. Mandal and S. Bhattacharya, "Customer satisfaction in Indian retail banking: scale development and validation," Int. J. Adv. Manag. Econ., vol. 3, no. 2, pp. 109-121, 2014.

[58] E. M. Abd-el-salam, A. Y. Shawky, and T. El-Nahas, "The impact of corporate image and reputation on service quality, customer satisfaction and customer loyalty: testing the mediating role. Case analysis in an international service company,” Bus. Manag. Rev., vol. 3, no. 2, pp. 177-196, 2013.

[59] J. J. Cronin, M. K. Brady, and G. T. M. Hult, "Assessing the effects of quality, value, and customer satisfaction on consumer behavioral intentions in service environments,” J. Retail., vol. 76, no. 2, pp. 193-218, 2000.

[60] A. Caruana, "Service loyalty: the effects of service quality and the mediating role of customer satisfaction,” Eur. J. Mark., vol. 36, no. 7, pp. 811-828, 2002.

[61] C. C. Cheng, S. Chiu, H. Hu, and Y. Chang, "A study on exploring the relationship between customer satisfaction and loyalty in the fast food industry: With relationship inertia as a mediator,” African J. Bus. Manag., vol. 5, no. 13, pp. 5118-5126, 2011.

[62] A. Katarachia, "Measuring service quality and satisfaction in Greek cooperative banking: an exploratory study,” Satisf. with Coop. Bank., vol. 26, pp. 55-75, 2013.

[63] Y.-T. Tu, C.-M. Wang, and H.-C. Chang, "Corporate brand image and customer satisfaction on loyalty: an empirical study of Starbucks coffee in Taiwan,” J. Soc. Dev. Sci., vol. 3, no. 1, pp. 24-32, 2012.

[64] G. S. Sureshchandar, C. Rajendran, and R. N. Anantharaman, "The relationship between service quality and customer satisfaction - a factor specific approach,” J. Serv. Mark., vol. 16, no. 4, pp. 363-379, 2002.

[65] A. Floh and H. Treiblmaier, "What keeps the e-banking customer loyal? A multigroup analysis of the moderating role of consumer characteristics on e-loyalty in the financial service industry," SSRN Electron. J., vol. 7, no. 2, pp. 97-110, 2006.

[66] A. O. da S. Fragata and P. A. Muñoz-gallego, "The importance of perceived service quality in banking loyalty for large business," Pecvnia, Monográfico, pp. 151-164, 2010.

[67] L. L. Kheng, O. Mahamad, and T. Ramayah, "The impact of service quality on customer loyalty: a study of banks in Penang, Malaysia,” Int. J. Mark. Stud., vol. 2, no. 2, pp. 57-66, 2010.

[68] D. Arora and A. Saxena, "Inter relationship of service quality aspects, customer satisfaction and customer loyalty in banking sector of India: a study of retail banking sector,” Int. J. Res. Bus. Manag., vol. 1, no. 4, pp. 1-8, 2013.

[69] R. Ladhari, N. Souiden, and I. Ladhari, "Determinants of loyalty and recommendation: The role of perceived service quality, 
emotional satisfaction and image," J. Financ. Serv. Mark., vol. 16, no. 2, pp. 111-124, 2011.

[70] I. Manduku, "Determinants of customer loyalty in the retail banking sector in Kenya," United States International University, 2013.

[71] M. Z. Sarwar, K. S. Abbasi, and S. Pervaiz, "The effect of customer trust on customer loyalty and customer retention: a moderating role of cause related marketing," Glob. J. Manag. Bus., vol. 12, no. 6, pp. 26-36, 2012.

[72] K. Damtew and V. Pagidimarri, "The role of ' trust ' in building customer loyalty in insurance sector- a study," IOSR J. Bus. Manag., vol. 14, no. 4, pp. 82-93, 2013.

[73] M. M. Akbar and N. Parvez, "Impact of service quality, trust, and customer satisfaction on customers loyalty,” ABAC J., vol. 29, no. 1, pp. 24-38, 2009.

[74] Rita Alfin, T. Alhabsji, U. Nimran, and Suharyono, "Effect of service quality and product puality to corporate image, customer's satisfaction and customer's Trust,” IOSR J. Bus. Manag., vol. 9, no. 6, pp. 01-09, 2013.

[75] P. V. Ranjith, "Service quality in banking," Int. J. Manag. Res. Rev., vol. 3, no. 9, pp. 3463-3468, 2013.

[76] F. Rubogora, "Service quality and customer satisfaction in selected banks in Rwanda," J. Bus. Financ. Aff., vol. 06, no. 01, pp. 1-11, 2017.

[77] R. Mosahab, O. Mahamad, and T. Ramayah, "Service quality, customer satisfaction and loyalty: a test of mediation," Int. Bus. Res., vol. 3, no. 4, pp. 72-80, 2010.

[78] T. L. Hong and M. Marimuthu, "Relationship between service quality and customer satisfaction: a study of Malaysian banking industry,” J. Technol. Manag. Technopreneursh., vol. 2, no. 2, pp. 53-72, 2014.

[79] C. M. Msoka and E. M. Msoka, "Determinants of customer retention in commercial banks in Tanzania," J. Financ. Bank Manag., vol. 2, no. 1, pp. 9-30, 2014.

[80] D. Ribbink et al., "Comfort your online customer: quality, trust and loyalty on the internet,” Manag. Serv. Qual., vol. 14, no. 6, pp. 446-456, 2004.

[81] S. U. A. Gillani, "Customer loyalty in financial sector: a case study of commercial banks in Southern Punjab," Int. J. Account. Financ. Report., vol. 4, no. 2, pp. 587-606, 2014.

[82] S.-M. Trif, "The influence of vverall satisfaction and trust," Manag. Mark. Challenges Knowl. Soc., vol. 8, no. 1, pp. 109-128, 2013.

[83] S. A. Mosavi and M. Ghaedi, "A survey on the relationship between trust, customer loyalty, commitment and repurchase intention," African J. Bus. Manag., vol. 6, no. 36, pp. 10089-10098, 2012.

[84] L. Bricci, A. Fragata, and J. Antunes, "The effects of trust, commitment and satisfaction on customer loyalty in the distribution Sector,” J. Econ. Bus. Manag., vol. 4, no. 2, pp. 173-177, 2016.

[85] R. Madjid, "Customer trust as relationship mediation between customer satisfaction and loyalty at Bank Rakyat Indonesia (BRI) Southeast Sulawesi,” Int. J. Eng. Sci., vol. 2, no. 5, pp. 48-60, 2013.
[86] K. C. Hu and M. C. Huang, "Effects of service quality, innovation and corporate image on Customer's satisfaction and loyalty of Air Cargo Terminal,” Int. J. Oper. Res., vol. 8, no. 4, pp. 36-47, 2011.

[87] A. Nurbasari and N. H. Harani, "Influence of customer relationship marketing and satisfaction of customer loyalty (Case Study: In Bank CIMB Niaga Lembong in Bandung)," Econ. World vol. 6, no. 2, pp. 98-107, 2018

[88] P. Jeevan, “Customer loyalty in retail banking,” Indian J. Sch. Res. Ahmedabad, pp. 1-10, 2014

[89] E. Cristobal, C. Flavia, and M. Guinalıu, "Perceived e-service quality (PeSQ) consumer satisfaction and web site loyalty," Manag. Serv. Qual., vol. 17, no. 3, pp. 317-340, 2007.

[90] G. Kaur, R. D. Sharma, and N. Mahajan, "Segmentation of bank customers by loyalty and switching intentions," Vikalpa, vol. 39, no. 4, pp. 75-89, 2014.

[91] R. V Krejcie and D. W. Morgan, "Determining sample size for research activities,” Educ. Psychol. Meas., vol. 30, pp. 607-610, 1970.

[92] M. Amin and Z. Isa, "An examination of the relationship between service quality perception and customer satisfaction: a SEM approach towards Malaysian Islamic banking,” Int. J. Islam. Middle East. Financ. Manag., vol. 1, no. 3, pp. 191-209, 2008.

[93] S. Hafeez and B. Muhammad, "The impact of service quality, customer satisfaction and loyalty programs on customer's loyalty: evidence from banking sector of Pakistan,” Int. J. Bus. Soc. Sci., vol. 3, no. 16, pp. 200-209, 2012.

[94] G. A. Churchill, "A paradigm for developing better measures of marketing constructs," J. Mark. Res., vol. XVI, pp. 64-73, 1979.

[95] C. Fornell and D. F. Larcker, "Evaluating Structural equation models with unobservable variables and measurement error," $J$. Mark. Res., vol. 18, no. 1, pp. 39-50, 1981.

[96] N. Kassim and N. A. Abdullah, "The effect of perceived service quality dimensions on customer satisfaction, trust, and loyalty in e-commerce settings: a cross cultural analysis,” Asia Pacific J. Mark. Logist., vol. 22, no. 3, pp. 351-371, 2010.

[97] M. R. A. Hamid, W. Sami, and M. H. M. Sidek, "Discriminant validity assessment: use of Fornell \& Larcker criterion versus HTMT criterion," J. Phys. Conf. Ser., 2017.

[98] E. K. Balemba, "Satisfaction des employés, satisfaction et rétention des clients et performance perçue,” Université de Mons, 2015.

[99] M. Brauer, "L’identification des processus médiateurs dans a recherche en psychologie," Annee. Psychol., vol. 100, no. 4, pp. 661-681, 2015.

[100] V. Beh Yin Yee, "A Study on the determinants of customer loyalty using internet banking website in Malaysia," University of Malaya, 2009

[101] N. Eakuru and N. M. Kamariah, "The application of Structural Equation Modeling (SEM) in Determining the antecedents of customer loyalty in banks in South Thailand,” Bus. Rev. Cambridge, vol. 10, no. 2, pp. 129-139, 2008.

[102] A. Ben Jemaa and N. Tournois, "Relationship marketing key concepts as relationship value determinant," J. Mark. Res. Case Stud., vol. 2014, pp. 1-17, 2014. 